\title{
ASTHMA-OBESITY NEUTROPHILIC INFLAMMATION AS A DISTINCT PHENOTYPE
}

\author{
Ibrahim M. El Akkary ${ }^{(1)}$, Mohamed El-Ghazaly ${ }^{(1)}$, Hussam EL-Dien M. Ghoneim ${ }^{(2)}$, Eman Y. \\ Khairy $^{(1)}$, Ola A. Salama ${ }^{(1)}$, Islam M. Abbas ${ }^{(1)}$
}

${ }^{(1)}$ Department of Clinical Physiology, Medical Research Institute, University of Alexandria, Egypt

${ }^{(2)}$ Department of Immunology, Medical Research Institute, University of Alexandria, Egypt

\begin{abstract}
:
Background \& objectives: Asthma in obese subjects has been suggested to differ from classical phenotypes of asthma. Obesity is associated with activation of innate immune response in which neutrophilic activation is a fundamental process. However, airway inflammation in obese asthmatics is not well characterized, but may involve neutrophils. The present work was designed to study the possible airway and systemic neutrophilic inflammation as a distinct feature of asthma in obese asthma phenotype. Methods: Study included 30 obese asthmatics (BMI $\geq 30 \mathrm{~kg} / \mathrm{m} 2$ ), 8 nonobese asthmatics (BMI $<25 \mathrm{~kg} / \mathrm{m} 2)$ and 7 normal non-obese subjects (BMI $<25 \mathrm{~kg} / \mathrm{m} 2$ ). Anthropometric measurements and pulmonary flow rates were assessed for all subjects. Methacholine inhalation challenge was performed only in asthmatics. Blood and sputum samples were tested for neutrophilic and eosinophilic counts, as well as levels of interleukin-8 (IL-8)and myeloperoxidase (MPO) enzyme, as markers of neutrophilic activity.

Results: There was no significant difference between obese and nonobese asthmatics as regard the mean value of the provocative dose of methacholine (PD20-FEV1). Compared to non-obese asthmatics, obese asthmatics demonstrated significantly higher blood and sputum neutrophilic counts and significantly lower blood and sputum eosinophilic counts. However, on comparing IL-8 and MPO levels between the obese asthmatic group and non-obese asthmatic group, there were insignificant trends toward increased serum and sputum levels of IL-8 and serum level of MPO in the obese asthmatic group. In asthmatic subjects, there was a significant positive correlation between BMI and serum MPO levels. Conversely, BMI showed significant negative correlations with both sputum eosinophilic count and blood absolute eosinophilic count. Conclusions: Findings suggest that neutrophil predominant airway inflammation is more likely to be a distinct inflammatory phenotype of asthma in obese asthmatic subjects, though further studies are needed to detect significant effects of obesity on markers of neutrophil activity in asthmatic subjects to shed more light on the possible role of neutrophilic inflammation in the association between obesity and asthma.
\end{abstract}

Keywords: Obesity, Bronchial asthma, Asthma phenotypes. has been suggested that obesity, as a chronic inflammatory disorder, could affect asthma by enhancing airway inflammation. $^{(3)}$

Some observations suggest that asthma in obese subjects may differ from classical phenotypes of asthma. ${ }^{(4)}$ These include the finding that weight loss in obese subjects is associated with a significant improvement in asthma symptoms, either with (5) or without $^{(6)}$ a significant improvement of airway hyperresponsiveness (AHR). Moreover, obese asthmatics report poor asthma control in response to standard asthma medication. ${ }^{(7)}$ suggesting that obesity produces a unique phenotype of asthma that requires a distinct therapeutic approach. However, the mechanisms by which obesity may enhance the occurrence of this distinct asthma phenotype need to be elucidated.

Obesity is associated with activation of innate immune response in which neutrophilic activation is a fundamental process. ${ }^{(8)}$ However, the impact of this systemic neutrophilic activation on the pattern of airway inflammation in obese asthmatics is not well characterized.

Data obtained from a large populationbased study(9) revealed that, although obesity was associated with asthma, there was no clear association with eosinophilic airway inflammation, suggesting that the

\section{INTRODUCTION}

The association between asthma andhanges in pulmonary mechanics,with a predominant neutrophilic obesity is poorly understood. Severacommon genetic determinants andnflammation. In turn, it was theoretically potential pathophysiologic mechanisms hormonal influences. ${ }^{(1,2)}$ Furthermore, ipossible that leptin, which is increased in 
obesity, may indirectly enhance neutrophilic airway inflammation and if present, this might potentially explain why obese asthmatics require increased levels of antiinflammatory treatment. In this context, leptin was found to be associated with higher neutrophil activation in peripheral blood. ${ }^{(10)}$

These observations together with the reported role of neutrophils in non-eosinophilic forms of asthma, may explain the severe and relatively resistant form of asthma to corticosteroid therapy ${ }^{(11,12)}$ in the obese-asthma phenotype.

Assessing neutrophilic inflammation using markers of neutrophil activity, such as interleukin-8 (IL-8) and myeloperoxidase (MPO), is more likely to evaluate neutrophilic inflammatory state rather than neutrophil cell count alone. ${ }^{(13)}$ IL-8 is a powerful chemoattractant and activator of neutrophils. In addition, IL-8 can be synthesized by neutrophils in response to various inflammatory mediators and therefore form a positive feedback loop that induces the accumulation of large numbers of neutrophils. ${ }^{(12,14)}$ MPO is an enzyme stored in azurophilic granules of polymorphonuclear neutrophils and released by activated neutrophils in the setting of inflammatory process. ${ }^{(15)}$

Accordingly, the present work was designed to study the potential involvement of airway and systemic neutrophilic inflammation as a distinct feature of asthma in obese asthma phenotype, by measuring both the inflammatory cell counts and neutrophil activity markers (IL-8 and MPO) in the sputum and blood of obese asthmatic subjects comparing their levels with non-obese asthmatics and normal (control) subjects 2. Subjects and Methods

\section{SUBJECTS}

38 asthmatic patients ( 7 males, 31 females) as defined by the American Thoracic Society ${ }^{(16)}$ recruited from patients attending to the Clinical Pulmonary Lab, Clinical Physiology Unit, Medical Research Institute, were included in this study. They were asymptomatic and their asthma was controlled and didn't have symptoms of respiratory infection within at least four weeks before the beginning of the study. Corticosteroids were withheld 2 weeks before the study. Other anti-asthma drugs were stopped 8 hours before the study. ${ }^{(17)}$ Thorough history taking and clinical examination were performed. The patients were selected and grouped according to their body mass index (BMI) into non-obese group; $\mathrm{BMI}<25$ $\mathrm{kg} / \mathrm{m} 2(\mathrm{n}=8)$ and obese group; BMI $\geq 30 \mathrm{~kg} / \mathrm{m} 2(\mathrm{n}=30)$. 7 normal non-obese subjects; BMI $<25 \mathrm{~kg} / \mathrm{m} 2$ (3 females, 4 males) were included in this study; none of them or their first degree relatives were suffering from asthma, or allergic diseases. They were non-smokers. None of them had symptoms of respiratory infection within eight weeks before the beginning of the study. An oral informed consent was obtained from each subject before performing the procedures according to the regulations adapted by the ethical committee of the Medical Research Institute.

\section{METHODS}

\section{1-Anthropometric Measurements}

Measurement of current body weight.

Measurement of body height.

Then BMI was calculated using the formula:

BMI (in $\mathrm{kg} / \mathrm{m} 2)(18)=\frac{\text { weight in kilog ram }}{\text { square of the height in meters }}$

Measurement of waist circumference (WC), according to the $\mathrm{WHO}(19)$ which specifies the measuring location at the circumference line half way between the lowest costal margin and the iliac crest.

\section{2- Physiological Studies}

A-Pulmonary function tests including, Forced vital capacity (FVC), Forced expiratory volume in one second (FEV1), FEV1/FVC\%, Forced expiratory flow rate at $25 \%, 50 \%$ and $75 \%$ of FVC (FEF25\%, FEF50\%, FEF75\% respectively) and maximum mid expiratory flow (MMEF) were measured using computerized dry spirometer (Jaeger, Germany) with automatic dosimeter for methacholine inhalation challenge. All measurements were performed according to the European Respiratory Society and American Thoracic Society protocol for spirometry standardization.(20)

B-Determination of bronchial reactivity by methacholine inhalation challenge method (only in asthmatics) using the five-breath dosimeter protocol according to the guidelines of the American Thoracic Society for methacholine inhalation challenge test.(17) If FEV1 fell more than $20 \%$ from baseline (or the highest concentration has been given), no further methacholine was given, inhaled salbutamol was administered and spirometry was repeated after $10 \mathrm{~min}$. PD20- FEV1 was computed.

\section{Sputum induction procedure ${ }^{(21)}$}

Sputum induction was carried out in subjects with a baseline FEV1 > 1.0 L. If FEV1 $>1.0 \mathrm{~L}$ but $<1.2 \mathrm{~L}$, sputum induction was performed with isotonic $0.9 \%$ saline. For subjects with FEV1 > 1.2 L, sputum induction was performed with $4.5 \%$ hypertonic saline.

\section{Induced sputum processing}

All sputum samples were processed as soon as they were collected. Mucus plugs were selected from saliva and dispersed with $0.1 \%$ dithiothreitol (DTT). For every $\mathrm{mL}$ of sputum, $4 \mathrm{~mL}$ of DTT was added. The tube was capped and placed on a rotating mixer for 30 minutes at room temperature, to ensure optimal cell dispersion. The supernatant was aliquoted and stored at $-80^{\circ} \mathrm{C}$ and the cell pellet for the cytospins was resuspended to a concentration of 1 x 106 cells $/ \mathrm{mL}$ using phosphate buffered saline.

\section{Sputum differential cell count ${ }^{(21)}$}

Cytospins were fixed in methanol and stained with May and Grunwald stain and subsequently visualized with Giemsa. 400 non-squamous cells were counted, with the squamous cell proportion recorded separately. Cells were identified by their morphology and the differential cell count was expressed as a percentage of non-squamous 
cells Chromotrope $2 \mathrm{R}$ staining was also performed to confirm the presence or absence of eosinophils. Sputum differential neutrophilic count was determined by light microscopy and absolute neutrophilic counts were

\section{Absolute neutrophilic and eosinophilic count in peripheral blood}

Peripheral venous blood samples were obtained from all subjects. One portion was allowed to clot in a serum separator tube (about 4 hours) at room temperature and then it was centrifuged at approximately $1000 \mathrm{X} \mathrm{g}$ for 15 min, aliquot and stored at $-20^{\circ} \mathrm{C}$ for measurement of IL- 8 and MPO. The other portion was taken into a glass tube containing ethylenediaminetetraacetic acid (EDTA) as anticoagulant and stored at $4^{\circ} \mathrm{C}$ before measurement of neutrophilic and eosinophilic count within 12 hours. After Leishman's staining, percentage of neutrophil and eosinophil cells was computed relative to the total number of white blood cells using a hemocytometer. The absolute count was computed by multiplying the total leukocyte count by the percentage of the cells.

6 Determination of neutrophilic inflammatory biomarkers

A) Determination of $\mathrm{IL-8}$ level in the supernatants of induced sputum and sera of all groups by ELISA technique using human IL-8/CXCL8 ELISA Kit (Boster Biological Technology Co., USA), according to the manufactures' instructions. Data were expressed as $\mathrm{pg} / \mathrm{ml}$.

B) Determination of myeloperoxidase (MPO) enzyme level in the supernatants of induced sputum and sera of all groups by ELISA technique using human Myeloperoxidase /MPO ELISA Kit (Boster Biological Technology Co., USA), according to the manufactures' instructions. Data were expressed as ng/ml.

\section{Statistical Analysis}

Data were analyzed using the Statistical Package for Social Sciences (SPSS ver.20 Chicago, IL, USA). The distributions of quantitative variables were tested for normality and revealed that most of the data were normally distributed, so parametric statistics were applied. Quantitative data were described using minimum, maximum, mean and standard deviation. ANOVA was used for comparing the three studied groups. Kruskal Wallis test was used to compare different groups for abnormally distributed quantitative variables. Correlations between 2 quantitative variables were done using Pearson correlation test. In all statistical tests, level of significance of 0.05 was used, below which the results considered to to be statistically significant.

\section{RESULTS}

The anthropometric data of asthmatic patients (obese and non-obese) and controls are presented in table (1).

\section{1-Physiological Results}

1-Pulmonary function parameters in asthmatic and control subjects are presented in table (2). There was a significant difference between the three groups as regard FEV1/FVC\% ( $\mathrm{P}=0.022)$, FEF25\% $(\mathrm{P}=0.005), \mathrm{FEF} 50 \%$ $(\mathrm{P}=0.000)$, FEF75\% $(\mathrm{P}=0.000)$ and MMEF $(\mathrm{P}=0.000)$. There was no significant difference between obese asthmatics and non-obese asthmatics as regard all pulmonary function parameters measured. (Data not shown)

\section{Methacholine inhalation challenge}

The provocational dose of methacholine that causes $20 \%$ reduction in $\mathrm{FEV}_{1}\left(\mathrm{PD}_{20-\mathrm{FEV} 1)}\right.$ in obese asthmatics and in nonobese asthmatics are presented in table (3). There was no significant difference in $\mathrm{PD}_{20-\mathrm{FEV} 1}$ between obese asthmatics and non-obese asthmatics.

2-Inflammatory biomarkers results (table 4, Figures 1, 2, 3, and 4)

There was a significant difference between the three groups as regard absolute neutrophilic and eosinophilic count in blood, total cell count in sputum and neutrophils and eosinophils in sputum $(\mathrm{P}=0.000$ for all).There was no significant difference between the three groups as regard levels of IL- 8 in sputum and serum, as well as MPO enzyme in sputum and serum. On comparing obese asthmatics with non-obese asthmatics, obese asthmatics demonstrated significantly higher blood absolute neutrophilic count and sputum neutrophilic count $(\mathrm{P}=0.044$ 0.001 respectively) and significantly lower blood absolute eosinophilic count and sputum eosinophilic count $(\mathrm{P}=0.000$ for all) than non-obese asthmatics. In addition, there were trends, although not significant, towards increased neutrophilic inflammatory markers (serum IL-8, sputum IL-8 and serum MPO) in obese compared with non-obese asthmatics.

Table (1): Anthropometric data of control subjects and asthmatic patients:

\begin{tabular}{|c|c|c|c|c|c|}
\hline \multirow{2}{*}{\multicolumn{2}{|c|}{ Anthropometric data }} & \multirow[t]{2}{*}{$\begin{array}{l}\text { Control subjects } \\
\quad(n=7)\end{array}$} & \multicolumn{2}{|c|}{$\begin{array}{l}\text { Asthmatics } \\
\quad(n=38)\end{array}$} & \multirow[t]{2}{*}{$\begin{array}{c}\text { Test of significance } \\
\text { P value }\end{array}$} \\
\hline & & & $\begin{array}{l}\text { Obese asthmatics } \\
(n=30)\end{array}$ & $\begin{array}{c}\text { Non obese asthmatics } \\
(\mathrm{n}=8)\end{array}$ & \\
\hline Age (year) & $\begin{array}{l}\text { Min. - Max. } \\
\text { Mean } \pm \text { SEM. }\end{array}$ & $\begin{array}{l}23-43 \\
29.57 \pm 2.57\end{array}$ & $\begin{array}{l}22-54 \\
36 \pm 1.66\end{array}$ & $\begin{array}{l}24-52 \\
32.25 \pm 3.69\end{array}$ & 0.197 \\
\hline Weight (kg) & $\begin{array}{l}\text { Min. - Max. } \\
\text { Mean } \pm \text { SEM. }\end{array}$ & $\begin{array}{l}49-90 \\
67.7 \pm 5.40\end{array}$ & $\begin{array}{l}75-135 \\
96.7 \pm 3.10\end{array}$ & $\begin{array}{l}53-65 \\
61.50 \pm 1.88\end{array}$ & $0.000 * *$ \\
\hline Height $(\mathrm{cm})$ & $\begin{array}{l}\text { Min. - Max. } \\
\text { Mean } \pm \text { SEM. }\end{array}$ & $\begin{array}{c}161-190 \\
168.8 \pm 3.63\end{array}$ & $\begin{array}{l}152-182 \\
162.23 \pm 1.47\end{array}$ & $\begin{array}{l}152-168 \\
163.75 \pm 1.88\end{array}$ & 0.151 \\
\hline
\end{tabular}

ata are expressed as mean \pm SEM. p: is determined using ANOVA test comparing obese asthmatics vs. non obese asthmatics vs. controls. $* *$ Denotes a $\mathrm{p}$ value $<0.001$ that was considered highly statistically significant. 
Table (2): pulmonary function parameters in control subjects and asthmatic patients:

\begin{tabular}{|c|c|c|c|c|c|}
\hline \multirow{2}{*}{\multicolumn{2}{|c|}{ Pulmonary function parameters }} & \multirow{4}{*}{$\begin{array}{c}\begin{array}{c}\text { Control } \\
(\mathbf{n}=7)\end{array} \\
72-109 \\
72 \pm 5.86\end{array}$} & \multicolumn{2}{|c|}{ Asthmatics } & \multirow[b]{2}{*}{$\begin{array}{c}\text { Test of significance } \\
\text { P value } \\
\end{array}$} \\
\hline & & & $\begin{array}{c}\text { Asthmatic obese patients } \\
(\mathbf{n}=\mathbf{3 0})\end{array}$ & $\begin{array}{c}\text { Asthmatic non obese patients } \\
(\mathrm{n}=8)\end{array}$ & \\
\hline \multirow{2}{*}{ FEV $_{1}$} & Min. - Max. & & $70-114$ & $70-112$ & \multirow[b]{2}{*}{ NS } \\
\hline & Mean \pm SEM & & $91.67 \pm 2.16$ & $90.50 \pm 4.26$ & \\
\hline \multirow{2}{*}{ FVC } & Min. - Max. & $84-102$ & $61-107$ & $80-106$ & \multirow{2}{*}{ NS } \\
\hline & Mean \pm SEM. & $84 \pm 1.99$ & $86.87 \pm 2.40$ & $90.63 \pm 2.96$ & \\
\hline \multirow{2}{*}{$\mathrm{FEV}_{1} / \mathrm{FVC} \%$} & Min. - Max. & $90-100$ & $64.1-95.5$ & $67.7-97.6$ & \multirow{2}{*}{$0.022 *$} \\
\hline & Mean \pm SEM. & $90 \pm 1.64$ & $88.47 \pm 2.40$ & $86.6 \pm 3.86$ & \\
\hline \multirow{2}{*}{ FEF $_{25 \%}$} & Min. - Max. & $85-129$ & $53-104$ & $46-107$ & \multirow{2}{*}{$0.005^{*}$} \\
\hline & Mean \pm SEM. & $85 \pm 6.32$ & $78.08 \pm 2.80$ & $75.13 \pm 7.12$ & \\
\hline \multirow{2}{*}{ FEF $_{\mathbf{5 0} \%}$} & Min. - Max. & $92-137$ & $29-109$ & $43-106$ & \multirow{2}{*}{$0.000 * *$} \\
\hline & Mean \pm SEM. & $92 \pm 7.07$ & $76.47 \pm 3.83$ & $74.33 \pm 8.24$ & \\
\hline \multirow{2}{*}{ FEF $_{75 \%}$} & Min. - Max. & $91-197$ & $17-113$ & $33-110$ & \multirow{2}{*}{$0.000 * *$} \\
\hline & Mean \pm SEM. & $91 \pm 15.84$ & $74.05 \pm 3.74$ & $77.84 \pm 11.21$ & \\
\hline \multirow[t]{2}{*}{ MMEF } & Min. - Max. & $90-157$ & $46-103$ & $41-105$ & \multirow{2}{*}{$0.000 * *$} \\
\hline & Mean \pm SEM. & $90 \pm 9.77$ & $80.03 \pm 2.50$ & $76.28 \pm 9.32$ & \\
\hline
\end{tabular}

$\mathbf{F E V}_{1}$ : Forced expiratory volume after one second, FVC: Forced vital capacity, $\mathbf{F E V}_{\mathbf{1}} / \mathbf{F V C} \%$ ratio between two values, $\mathbf{F E F}_{2}$ : Forced expiratory flow at $25 \%$ of $\mathbf{F V C}, \mathbf{F E F}_{50 \%}$ : Forced expiratory flow at $50 \%$ of $\mathbf{F V C}, \mathbf{F E F}_{75 \%}$ : Forced expiratory flow at $75 \%$ of FVC, MMEF: Maximum mid-expiratory flow rate. All data are expressed as percent predicted except for $\mathrm{FEV}_{1} / \mathrm{FVC}$ which is expressed as absolute value. Data are expressed as mean \pm SEM. P: is determined using ANOVA test comparing obese asthmatics vs. non obese asthmatics vs. control.* Denotes a p value $<0.05$ that was considered statistically significant. $* *$ Denotes a p value $<0.001$ that was considered highly statistically significant. 1

Table (3): Provocational dose (mg) of methacholine that causes $20 \%$ reduction in $\mathrm{FEV}_{1}\left(\mathrm{PD}_{20 \text {-FEv1 }}\right)$ of asthmatic patients (obese, nonobese):

\begin{tabular}{|c|c|c|c|}
\hline $\mathrm{PD}_{20-\mathrm{FEV} 1}(\mathrm{mg})$ & $\begin{array}{c}\text { Obese Asthmatic patients } \\
\qquad(n=30)\end{array}$ & $\begin{array}{c}\text { Non obese Asthmatic patients } \\
(\mathrm{n}=8)\end{array}$ & $\begin{array}{c}\text { Test of significance } \\
\text { P value }\end{array}$ \\
\hline Min. -Max. & $0.0011-0.19$ & $0.0010-0.13$ & 0.477 \\
\hline Mean \pm SEM & $0.045 \pm 0.01$ & $0.034 \pm 0.02$ & \\
\hline
\end{tabular}

Data are expressed as mean \pm SEM. $P$ : is determined using student $t$ test comparing obese asthmatics vs. non- obese asthma

Table (4): Inflammatory biomarkers in control subjects and asthmatic patients

\begin{tabular}{|c|c|c|c|c|c|}
\hline \multirow{2}{*}{\multicolumn{2}{|c|}{ Inflammatory Biomarkers }} & \multirow{2}{*}{$\begin{array}{c}\text { Control } \\
(\mathrm{n}=7)\end{array}$} & \multicolumn{2}{|c|}{ Asthmatic patients } & \multirow{2}{*}{$\begin{array}{c}\text { Test of } \\
\text { significance } \\
\text { P value } \\
\end{array}$} \\
\hline & & & $\begin{array}{c}\text { Asthmatic obese } \\
(\mathbf{n}=\mathbf{3 0})\end{array}$ & $\begin{array}{l}\text { Asthmatic non obese } \\
(\mathbf{n}=8)\end{array}$ & \\
\hline IL-8 serum (pg/ml) & $\begin{array}{l}\text { Min. }- \text { Max. } \\
\text { Mean } \pm \text { SEM. }\end{array}$ & $\begin{array}{l}312-469 \\
334.43 \pm 22.30\end{array}$ & $\begin{array}{l}312-2361 \\
543.32 \pm 98.73\end{array}$ & $\begin{array}{l}312-558 \\
353.87 \pm 30.31\end{array}$ & NS \\
\hline & Median & 312 & 312 & 312 & \\
\hline IL-8 sputum (pg/ml) & $\begin{array}{l}\text { Min. - Max. } \\
\text { Mean } \pm \text { SEM. }\end{array}$ & $\begin{array}{l}312-787 \\
427.71 \pm 70.15\end{array}$ & $\begin{array}{l}65-5474 \\
908.46 \pm 264.8\end{array}$ & $\begin{array}{l}312-3586 \\
735.25 \pm 407.5\end{array}$ & NS \\
\hline & Median & 312 & 312 & 312 & \\
\hline MPO serum (ng/ml) & $\begin{array}{l}\text { Min. - Max. } \\
\text { Mean } \pm \text { SEM. }\end{array}$ & $\begin{array}{l}57.9-82.7 \\
66.57 \pm 2.96\end{array}$ & $\begin{array}{l}26.6-149.5 \\
69.91 \pm 4.81\end{array}$ & $\begin{array}{l}39.3-71.1 \\
55.6 \pm 4.18\end{array}$ & NS \\
\hline MPO sputum (ng/ml) & $\begin{array}{l}\text { Min. }- \text { Max. } \\
\text { Mean } \pm \text { SEM. }\end{array}$ & $\begin{array}{l}30.7-239 \\
89.1 \pm 25.82\end{array}$ & $\begin{array}{l}15.20-239.4 \\
77.51 \pm 13.34\end{array}$ & $\begin{array}{l}21.1-277.5 \\
80.81 \pm 28.89\end{array}$ & NS \\
\hline $\begin{array}{l}\text { Absolute neutrophilic count } \\
\text { in peripheral blood }\left(\text { cell } / \mathrm{ml}^{3}\right)\end{array}$ & $\begin{array}{l}\text { Min. - Max. } \\
\text { Mean } \pm \text { SEM. }\end{array}$ & $\begin{array}{l}1200-6300 \\
3157.14 \pm 755.9\end{array}$ & $\begin{array}{l}1500-8300 \\
4420 \pm 409.4\end{array}$ & $\begin{array}{l}1100-5600 \\
2662.50 \pm 512.7\end{array}$ & $0.000^{* *}$ \\
\hline $\begin{array}{l}\text { Absolute eosinophilic count } \\
\text { in peripheral blood }\left(\text { cell } / \mathrm{ml}^{3}\right)\end{array}$ & $\begin{array}{l}\text { Min. - Max. } \\
\text { Mean } \pm \text { SEM. }\end{array}$ & $\begin{array}{l}150-350 \\
242.86 \pm 25.32\end{array}$ & $\begin{array}{l}180-550 \\
363.33 \pm 18.64\end{array}$ & $\begin{array}{l}500-850 \\
643.75 \pm 38.31\end{array}$ & $0.000^{* *}$ \\
\hline $\begin{array}{l}\text { Total cell count in sputum }\left(10^{6}\right. \\
\text { cells/mL) }\end{array}$ & $\begin{array}{l}\text { Min. - Max. } \\
\text { Mean } \pm \text { SEM. }\end{array}$ & $\begin{array}{l}0.46-1.80 \\
1.19 \pm 0.16\end{array}$ & $\begin{array}{c}1.80-4.50 \\
2.87 \pm 0.15\end{array}$ & $\begin{array}{l}1.80-4.00 \\
2.72 \pm 0.25\end{array}$ & $0.000^{* *}$ \\
\hline $\begin{array}{l}\text { Neutrophils in sputum } \quad\left(1^{6}\right. \\
\text { cells/mL })\end{array}$ & $\begin{array}{l}\text { Min. - Max. } \\
\text { Mean } \pm \text { SEM. }\end{array}$ & $\begin{array}{l}22-0.80 \\
0.5 \pm 0.07\end{array}$ & $\begin{array}{r}0.55-3.00 \\
1.46 \pm 0.12\end{array}$ & $\begin{array}{c}0.20-1.09 \\
0.6 \pm 0.10\end{array}$ & $0.000^{* *}$ \\
\hline $\begin{array}{l}\text { Esinophils in sputum } \\
\left(10^{6} \text { cells/mL }\right)\end{array}$ & $\begin{array}{l}\text { Min. }- \text { Max. } \\
\text { Mean } \pm \text { SEM. }\end{array}$ & $\begin{array}{l}0.005-0.020 \\
0.010 \pm 0.002 \\
\end{array}$ & $\begin{array}{c}0.050-1.800 \\
0.46 \pm 0.08 \\
\end{array}$ & $\begin{array}{l}0.70-1.9 \\
1.18 \pm 0.14 \\
\end{array}$ & $0.000^{* * *}$ \\
\hline
\end{tabular}




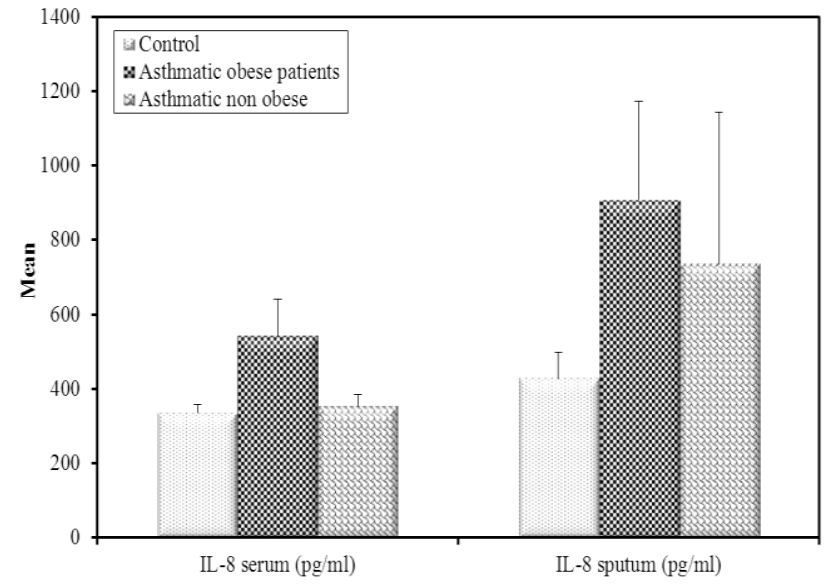

Fig. (1): Mean value of interleukin-8 (IL-8) (pg/ml) in sera and sputum of the three comparison groups

- There is no Significant difference between three groups

- There is no significant difference between obese asthmatics and nonobese asthmatics

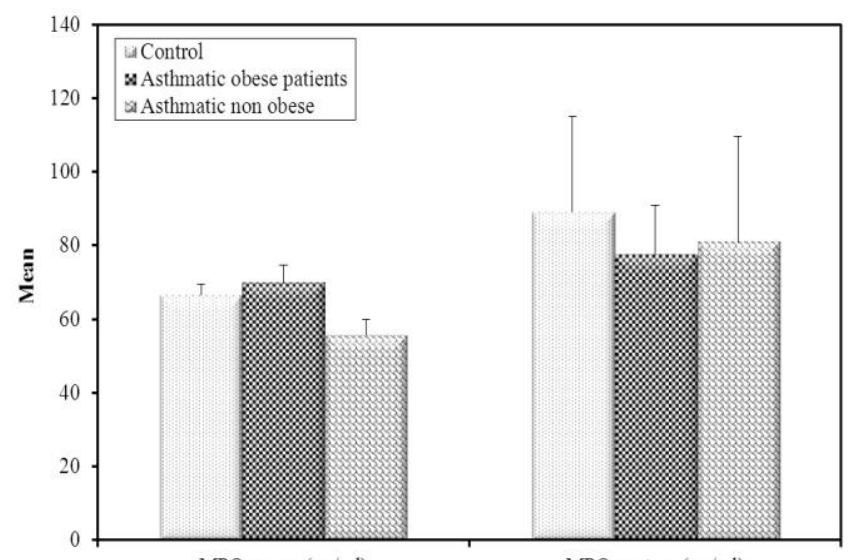

MPO serum (ng/ml)

MPO sputum (ng/ml)

Fig. (2): Mean value of myeloperoxidase enzyme (MPO) (ng/ml) in sera and sputum of the three comparison groups

- There is no significant difference between three groups

- There is no significant difference between obese asthmatics and non-obese asthmatics

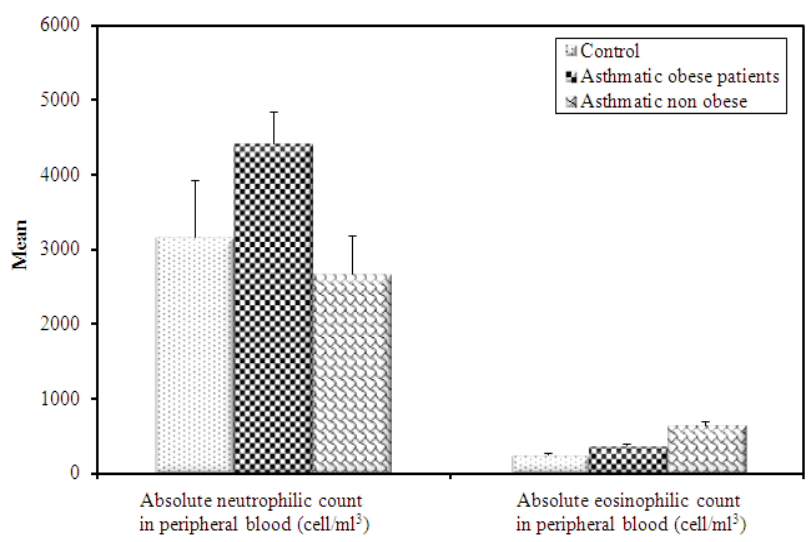

Fig. (3): Mean value of absolute neutrophilic count $\left(\mathrm{cell} / \mathrm{ml}^{3}\right)$ and absolute eosinophilic count $\left(\right.$ cell/ $\left.\mathrm{ml}^{3}\right)$ in peripheral blood of the three comparison groups

- Signifisant difference as compared obese asthmatics, non-obese asthmatics to control group

- Signifant difference as compared obese asthmatics and non-obese asthmatics

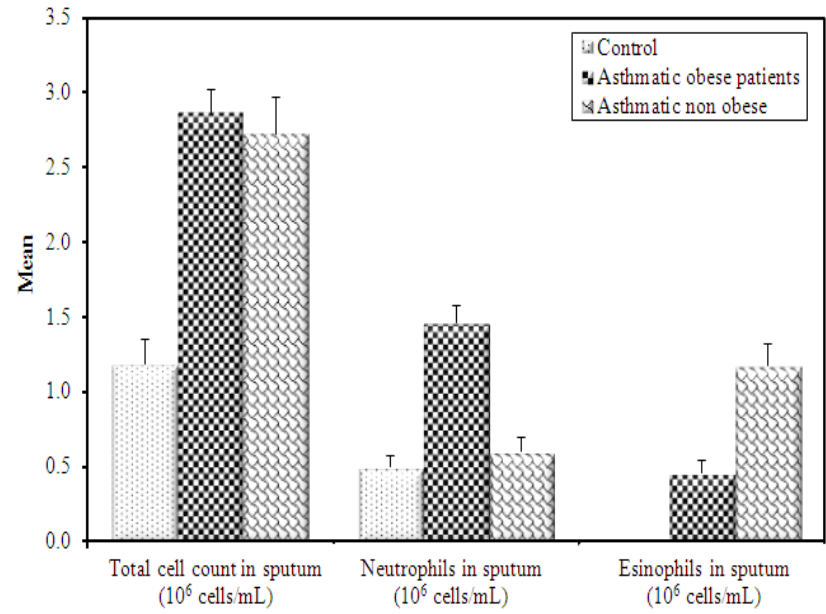

Fig. (4): Mean value of total cell count $\left(10^{6}\right.$ cells $\left./ \mathrm{ml}\right)$, neutrophils (polymorphs) $\left(10^{6}\right.$ cells $\left./ \mathrm{ml}\right)$ and eosinophils $\left(10^{6}\right.$ cells $\left./ \mathrm{ml}\right)$ in sputum of the three comparison groups.

- Sisnificant difference as compared obese asthmatics, nonobese asthmatics to control group

- Sificant difference as compared obese asthmatics and non-obese asthmatics

3 The obese asthmatic group was subdivided according to BMI into three classes:

Class I: 30.0 to $34.9 \mathrm{~kg} / \mathrm{m}^{2}$, Class II: 35.0 to $39.9 \mathrm{~kg} / \mathrm{m}^{2}$ and Class III: $\geq 40 \mathrm{~kg} / \mathrm{m}^{2}$. By comparing the data of these three groups considering physiological and inflammatory biomarkers, there was no significant difference between the three classes, except for weight, BMI and WC; meaning that there is no considerable difference could be detected between the different degrees of obesity as regard airway inflammation, or mechanical effect of obesity on asthma.

4 Significant correlations between body mass index and different variables among asthmatics (obese and nonobese): (Figures 5-7)

A. Body mass index (BMI) significantly positively correlated with myeloperoxidase enzyme (MPO) level in serum

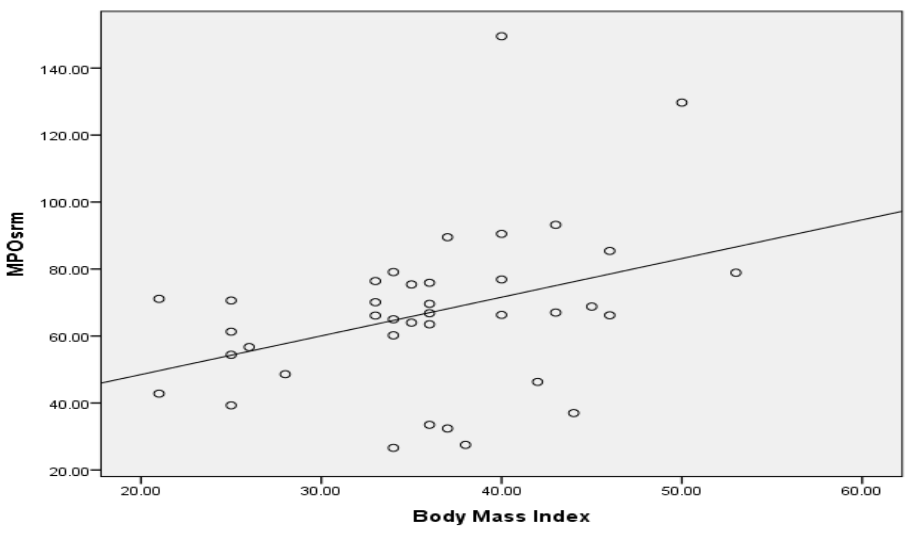

Fig.(5): Scatter plot diagram demonstrating the correlation between body mass index (BMI) $(\mathrm{kg} / \mathrm{m} 2)$ and myeloperoxidase enzyme (MPO) in serum (ng/ml)

- The line represents the line of identity

- The point represents a case among obese and non obese asthmatics 
- Body mass index (BMI) significantly negatively correlated with blood absolute eosinophilic count

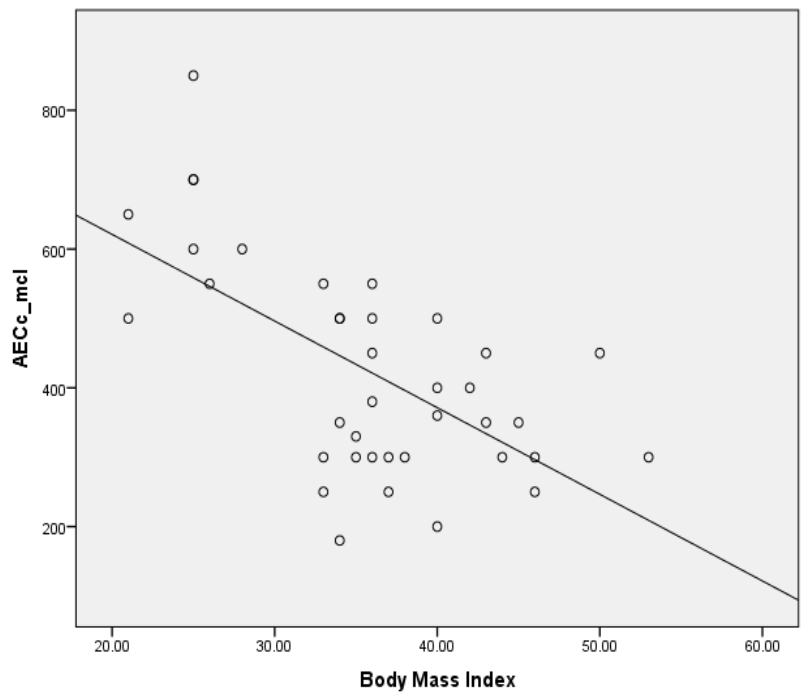

asthmatics. In addition, there were trends, although not significant, towards increased neutrophilic inflammatory markers (serum IL-8, sputum IL-8 and serum MPO) in obese asthmatics compared with non-obese asthmatics. However, there was a significant correlation between BMI and serum levels of MPO. Taken together, these data could postulate that obese asthmatics have a more neutrophilic pattern of inflammation even in chronic stable asthma status and this may reflect persistent lowgrade inflammation in obese asthmatics.

Neutrophilia has been associated with severe asthma and was generally seen in corticosteroid treated patients. Corticosteroids inhibit neutrophil apoptosis, and in some settings, contribute to neutrophilic activation, implicating that corticosteroid treatment itself is likely to have some relation to development of neutrophilia. ${ }^{(22)}$ Lung neutrophilia in asthmatics has been associated with lower lung function, more trapping of air, thickened airway walls and greater expression of matrix metalloproteinases than are seen in people with non-neutrophilic asthma, but

Fig.(6): Scatter plot diagram demonstrating the correlation between bołf not been associated with increased airway mass index (BMI) $\left(\mathrm{kg} / \mathrm{m}^{2}\right)$ and blood absolute eosinophilic cohyperresponsiveness. ${ }^{(23-25)}$ Increased neutrophil level has $\left(\right.$ cell $\left./ \mathbf{m l}^{3}\right)$

- The line represents the line of identity

- The point represents a case among obese and non obese asthmatics been also reported in stable asthma. ${ }^{(26,27)}$

A cluster analysis performed by Halder et $a l^{(28)}$ identified a unique asthma phenotype: a population that is obese and predominantly female, with absence of eosinophilia. Furthermore, inverse relationships between either BMI or WC with sputum eosinophilia in asthmatics were found. ${ }^{(4)}$ These findings are suggestive of obese asthmatics as a distinct phenotype characterized by non-eosinophilic airway inflammation. This non-eosinophilic phenotype could represent neutrophilic asthma.

Indeed, neutrophils have been shown to be more highly activated in obesity both in the circulation and adipose tissue vasculature ${ }^{(29,30)}$, indicating that the characteristic low-grade inflammation seen in obesity appears to be the result of chronic activation of the innate immune response. It is possible that this inflammation extends to airways of susceptible individuals, leading to increased levels of airway neutrophils. This may be explained by the effect of leptin, as it promotes T-helper type 1 cell differentiation and increases activation of neutrophils via tumor necrosis factor alpha (TNF- $\alpha){ }^{(10)}$ In a mouse pneumococcal pneumonia model ${ }^{(31)}$, exogenous leptin stimulated the innate immune response leading to increased neutrophils in bronchoalveolar lavage fluid (BALF). Because leptin is strongly related to obesity, the

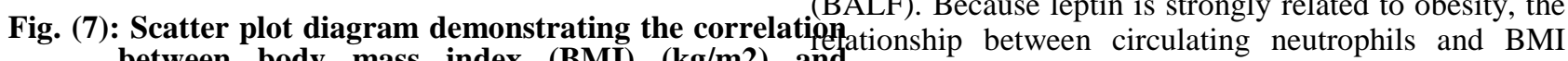
between body mass index (BMI) (kg/m2) sputum eosinophils (106 cells/ml)

- The line represents the line of identity

- The point represents a case among obese and non obese asthmatics

\section{DISCUSSION}

In the current study, obese-asthmatics demonstrated an increase in the mean level of neutrophils in both sputum and peripheral blood compared with non-obese would be expected to follow a similar pattern. However, it has been observed that there was no relationship between plasma leptin and airway neutrophils. ${ }^{(32)}$ Assessment of airway leptin level may provide more insight.

The neutrophilic predominant airway inflammation in our asthmatics may suggest that the "obese-asthma" phenotype may be associated with alterations in airway leukocytes. This is in agreement with a couple of studies which demonstrated that obese asthmatics have a higher 
level of neutrophilic inflammation, as reflected by both a higher percentage of sputum neutrophils and increased blood neutrophil counts; however, the increase in neutrophils was only seen in female obese asthmatics and not in male obese asthmatics. ${ }^{(32,33)}$

In the present study, we found significant negative correlations between BMI and eosinophilic counts, both in the sputum and peripheral blood in the asthmatic subjects. Yet we could not demonstrate a clear correlation between BMI and neutophilic counts; however, a larger sample size would probably have been needed to detect such effect.

It has been demonstrated that the concentration of IL-8 in sputum was higher in severe asthma ${ }^{(11)}$ and there were correlations between sputum neutrophil numbers, IL-8 and MPO where the production of IL- 8 by neutrophil can contribute to additional neutrophil recruitment and activation. The current study demonstrates relative elevations of IL-8 and MPO in obese asthmatics compared to non-obese asthmatics, inspite of similar severity of asthma as assessed by the measured pulmonary function and bronchial hyperreactivity. So, it could be supposed that obesity may independently activate innate immune response leading to a more neutrophilic pattern of airway inflammation. In agreement, IL-8 was reported to be increased in proportion to BMI. ${ }^{(34)}$

Additionally, in the present study, we found positive correlation between serum levels of MPO and BMI in the asthmatic subjects. MPO is a heme containing peroxidase expressed abundantly in neutrophils and released from secondary granules following neutrophil activation. ${ }^{(15)}$ So our observations would suggest that obesity related neutrophilic inflammation has at least a synergistic effect on existing airway inflammation. Sustained release of these inflammatory products more than the capacity of their inhibitors implicates the role of neutrophils in airway injury and remodeling in chronic persistent asthma.

The present study demonstrated that obesity by itself is not sufficient to alter airway responsiveness to methacholine as there was no significant difference between obese and non-obese asthmatics as regard the mean value of $\mathrm{PD}_{20-\mathrm{FEV} 1}$. There was no significant correlation between $\mathrm{PD}_{20-\mathrm{FEV} 1}$ and the $\mathrm{BMI}$ or the inflammatory markers. This is in agreement with studies that reported no increase in airway responsiveness with increasing $\mathrm{BMI}^{(35,36)}$ or serum IgE. ${ }^{(37)}$ Our results could be explained by the finding that both asthmatic groups (obese and non-obese) in this study demonstrated similar baseline pulmonary function data despite having different degree of sub-acute airway inflammation.

In contrast, other studies have reported positive correlations between AHR and both $\mathrm{BMI}^{(38)}$ and inflammatory markers. ${ }^{(39,40)}$ One study ${ }^{(41)}$ also noted a differing effect of obesity on AHR in female versus male subjects. Grouping subjects of both sexes together could thus obscure or attenuate any sex specific effects of obesity. Some studies describe a role for sex in the relationship between obesity and asthma. ${ }^{(42,43)}$ So, studies utilizing advanced measurement of lung and airway mechanics may be necessary to fully understand the relationship between obesity and AHR.

\section{CONCLUSIONS}

In conclusion, neutrophil predominant airway inflammation is more likely to be a distinct inflammatory phenotype of asthma in obese asthmatic subjects. This stems from the finding that the mean value of neutrophil in peripheral blood and sputum was significantly higher in obese compared to non-obese asthmatics. Regarding neutrophilic inflammatory markers, there were insignificant trends towards increased serum levels of IL8 and MPO and sputum level of IL- 8 in obese asthmatic group associated with significant correlation between BMI and serum MPO. So, obesity likely results in a unique asthma phenotype that will require the development of a distinct therapeutic approach. Future studies, in both animal and human, might examine neutrophil trafficking, cell signaling and difference in innate and adaptive immune response in the obese asthmatics.

\section{REFERENCES}

1. Boran P, Tokuc G, Pisgin B, Oktem S, Yegin Z, Bostan O. Impact of obesity on ventilatory function. J Pediatr 2007; 83: 171-6.

2. Sood A, Qualls C, Arynchyn A, Beckett WS, Gross $\mathrm{MD}$, Steffe MW, et al. Obesity-Asthma Association: Is it explained by systemic oxidant stress? Chest 2009; 136: 1055-62.

3. Sutherland TJ, Cowan JO, Young S, Goulding A, Grant A M, Williamson A, et al. The association between obesity and asthma: Interactions between systemic and airway inflammation. Am J Respir Crit Care Med 2008; 178: 469-75.

4. Wenzel SE. Asthma phenotypes: the evolution from clinical to molecular approaches. Nature medicine 2012; 18 (5): 716-25.

5. Dixon AE, Pratley RE, Forgione PM, Kaminsky DA, Whittaker-Leclair LA, Griffes LA, et al. Effects of obesity and bariatric surgery on airway hyperresponsiveness, asthma control, and inflammation. J Allergy Clin Immunol 2011; 128 (3): 508-15.

6. Zerah-Lancner F, Boyer L, Rezaiquia-Delclaux S, D'Ortho MP, Drouot X, Guilloteau-Schoennagel I, et al. Airway responsiveness measured by forced oscillation technique in severely obese patients, before and after bariatric surgery. J Asthma 2011; 48(8): 818-23.

7. Sutherland ER, Goleva E, Strand M, Beuther DA, Leung DY. Body mass and glucocorticoid response in asthma. Am J Respir Crit Care Med 2008; 178: 682-7.

8. Lumeng $\mathrm{CN}$. Innate immune activation in obesity. Molecular aspects of medicine 2013; 34(1): 12-29.

9. Scott HA, Gibson PG, Garg ML, Smart J, Wood LG. Neutrophilic airway inflammation links asthma and obesity. Am J Respir Crit Care Med 2009; 179: 5514. 
10. Zarkesh-Esfahani H1, Pockley AG, Wu Z, Hellewell PG, Weetman AP, Ross RJ. Leptin indirectly activates human neutrophils via induction of TNF-alpha. J Immunol 2004; 172: 1809-14.

11. Ordonez CL, Shaughnessy TE, Mattahy MA, Fahy JV. Increased neutrophil numbers and IL-8 levels in airway secretions in acute severe asthma: clinical and biologic significance. Am J Respir Crit Care Med 2000; 161:1185-90.

12. Monteseirín J. Neutrophils and Asthma. J Investig Allergol Clin Immunol 2009; 19(5): 340-54.

13. Cowburn AS, Condliffe AM, Farahi AN, Summer C, Chilver ER. Advances in neutrophil biology: clinical implications. Chest 2008; 134: 606-12.

14. Henkels KM, Frondorf K, Gonzalez-Mejia ME, Doseff AL, Gomez-Cambronero J. IL-8-induced neutrophil chemotaxis is mediated by Janus kinase 3 (JAK3). FEBS letters 2011; 585(1): 159-66.

15. van der Veen BS, de Winther MP, Heeringa $P$. Myeloperoxidase: molecular mechanisms of action and their relevance to human health and disease. Antioxid Redox Signal 2009; 11: 2899-937.

16. American Thoracic Society. Standards for the diagnosis and care of patients with chronic obstructive pulmonary disease (COPD) and asthma. AM Rev Respir Dis 1987; 136: 225-44.

17. American Thoracic Society. Guidelines for methacholine and exercise challenge testing. Am J Respir Crit Care Med 2000; 161: 309-29.

18. The National Institutes of health/National Health, Lung, and Blood Institute. Clinical Guidelines on the Identification, Evaluation and Treatment of Overweight and Obesity in Adults. The evidence report. NIH Publication 1998; 56-62.

19. World Health Organization (WHO). The World Health Report, 2002. Quoted from: Magnani K, Cataneo A. Respiratory muscle strength in obese individuals and influence of upper-body fat distribution. Sao Paulo Med J 2007; 125: 215-9.

20. Pellegrino R, Viegi G, Brusasco G, Crapo R, Burgos F, Casaburi $\mathrm{F}$, et al. Interpretative strategies for lung function tests series "ATS/ERS task force: standardisation of lung function testing". Eur Respir J 2005; 26: 948-68.

21. Baines KJ. Molecular pathogenesis of noneosinophilic asthma. B. BiomedSci (Hons) PHD thesis, University of Newcastle, Faculty of Health, School of Biomedical Sciences, 2007

22. Ruiz LM, Bedoya G, Salazar J, García de O D, Patino PJ. Dexamethasone inhibits apoptosis of human neutrophils induced by reactive oxygen species. Inflammation 2002; 26: 215-22.

23. Woodruff PG, Khashayar R, Lazarus SC, Janson S, Avila P, Boushey HA, et al. Relationship between airway inflammation, hyperresponsiveness, and obstruction in asthma. J Allergy Clin Immunol 2001; 108: 753-8.

24. Simpson JL, Scott RJ, Boyle MJ, Gibson PG. Differential proteolytic enzyme activity in eosinophilic and neutrophilic asthma. Am J Respir Crit Care Med 2005; 172: 559-65.

25. Busacker A, Newell JD Jr, Keefe T, Hoffman EA, Granroth JC, Castro M, et al. A multivariate analysis of risk factors for the air-trapping asthmatic phenotype as measured by quantitative CT analysis. Chest 2009; 135(1):48-56.

26. Green RH, Brightling CE, Woltmann G, Parker D, Wardlaw AJ, Pavord ID. Analysis of induced sputum in adults with asthma: identification of subgroup with isolated sputum neutrophilia and poor response to inhaled corticosteroids. Thorax 2002; 57:875-9.

27. Simpson JL, Scott R, Boyle M, Gibson PG. Inflammatory subtypes in asthma: assessment and identification using induced sputum. Respirology 2006; 11:54-61.

28. Haldar P, Pavord ID, Shaw DE, Berry MA, Thomas M, Brightling CE, et al. Cluster analysis and clinical asthma phenotypes. Am J Respir Crit Care Med 2008; 178:218-24.

29. Nijhuis J1, Rensen SS, Slaats Y, van Dielen FM, Buurman WA, Greve JW. Neutrophil activation in morbid obesity, chronic activation of acute inflammation. Obesity 2009; 17: 2014-8.

30. Shah TJ, Leik CE, Walsh SW. Neutrophil infiltration and systemic vascular inflammation in obese women. Reprod Sci 2010; 17: 116-24.

31. Mancuso P1, Huffnagle GB, Olszewski MA, Phipps J, Peters-Golden M. Leptin corrects host defense defects after acute starvation in murine pneumococcal pneumonia. Am J Respir Crit Care Med 2006; 173: 212-8.

32. Scott HA, Gibson PG, Garg ML, Wood LG. Airway inflammation is augmented by obesity and fatty acids in asthma. Eur Respir J 2011; 38(3): 594-602.

33. Telenga ED, Tideman SW, Kerstjens HAM, ten Hacken NHT, Timens W, Postma DS, van den Berge M. Obesity in asthma: more neutrophilic inflammation as a possible explanation for a reduced treatment response. Allergy 2012; 67: 1060-8.

34. Bruun JM, Lihn AS, Madan AK, Pedersen SB, Schiøtt KM, Fain JN, et al. Higher production of IL-8 in visceral vs. subcutaneous adipose tissue. Implication of nonadipose cells in adipose tissue. Am J Physiol Endocrinol Metab 2004; 286(1): 8-13.

35. Schachter LM, Salome CM, Peat JK, Woolcock AJ. Obesity is a risk for asthma and wheeze but not airway hyperresponsiveness. Thorax 2001; 56: 4-8.

36. Bustos $\mathrm{P}$, Amigo H, Oyarzun M, Rona RJ. Is there a causal relation between obesity and asthma? Evidence from Chile. Int J Obes Relat Metab Disord 2005; 29: 804-9.

37. Liu SF, Lin MC, Chang HW. Relationship of allergic degree and PC20 level in adults with positive methacholine challenge test. Respiration 2005; 72(6): 612-6.

38. Chouchane A, Miâdi-Messaoud H, Ghannouchi I, Rouatbi S, Zbidi A, Tabka Z. Obesity induced bronchopulmonary hyperresponsiveness in Tunisian women. Int J Obes 2010; 34(6): 1078-85.

39. Chinn S, Jarvis D, Burney P. Relation of bronchial responsiveness to body mass index in the ECRHS. European Community Respiratory Health Survey. Thorax 2002; 57 (12): 1028-33.

40. Sharma S, Tailor A, Warrington R, Cheang M. Is obesity associated with an increased risk for airway hyperresponsiveness and development of asthma? Allergy, Asthma, and Clinical Immunology: Official Journal of the Canadian Society of Allergy and Clinical Immunology 2008; 4(2): 51-8.

41. Huang SL, Shiao G, Chou P. Association between body mass index and allergy in teenage girls in Taiwan. Clin Exp Allergy 1999; 29: 323-9.

42. Ford ES. The epidemiology of obesity and asthma. J Allergy Clin Immunol 2005; 115: 897-910.

43. Shore SA, Johnston RA. Obesity and asthma. Pharmacol Ther 2006; 110: 83-102. 